paths of thought. He had been suffering from illhealth for about a year, but he carried on his research work until his death took place in London.

Freund was born in Vienna in 1863 . He graduated as an M.D. at the University of Vienna in 1886. His first publication, "Zur Diagnose des Carcinoms", was published in 1885 , when he was still a student. Dissatisfied with the predominantly toxicological and hygienic trend of the type of medical chemistry taught at that time, Freund proceeded in 1890 to found his own biochemical laboratory, which became attached to a large Viennese hospital. Its purpose was to put ehemical research at the disposal of the clinics. 'It was the first biochemical laboratory in Austria, and one of the first of its kind in the world. The importance of this laboratory for the development of biological and clinical chemistry in the old medical centre of Vienna was very great indeed. The results of the activities of his laboratory will be found in many volumes of Hofmeister's Beitraege, as well as in the first 255 volumes of the Biochemische Zeitschrift.

During this time, Freund's interests were focused on a variety of problems: the isolation of different serum globulins; the role of the intestine in protein metabolism; the presence of albumoses in blood and urine; the composition of urine in infections, especially pneumonia, and in other pathological conditions; the presence of specific nucleo-proteinases in urine; the development of simple methods for the isolation and determination of nitrogen-containing substances in urine, among them of the colloidal fraction of the so-called oxyproteinic acids. The inhibition of blood clotting by keeping the blood in paraffinized vessels was first observed by Freund. $\mathrm{He}$ isolated cellulose from miliary tubercles and based a treatment of tuberculosis on the exclusion of cellulose from the diet.

The year 1912 brought a decisive reorientation of Freund's work, which from now on became predominantly connected with cancer research. Jointly with his devoted co-worker, Dr. Gisa Kaminer, he discovered that normal blood serum has the power of dissolving carcinoma cells, whereas blood serum of carcinoma patients does not. Thus the first serological cancer reaction was found. Freund himself linked up his great discovery with yet another concept, that of cancer disposition, and he deduced the possibility of diagnosing cancer in its earliest stages, as well as predisposition to this disease. It is sometimes not realized that Freund's cytolytic reaction is an independent experimental fact which has been confirmed beyond doubt. Freund and his collaborators then proceeded to connect the serological changes with changes in the intestinal bacteriological flora. He tried to control this flora by intestinal disinfection and, above all, by a certain diet, the essential features of which were high protein and low carbohydrate content, complete absence of animal fats, and their replacement by vegetable fats. This diet was tried on animals with experimental cancer as well as on human cases; many inoperable cases showed appreciable, sometimes very great, improvement. Again Freund had broken new ground by demonstrating results the importance of which remains independent of the background of his theory.

At this stage Freund, who had retired from the University, found the interest and powerful support of Mr. Frederick F. A. Pearson, who founded a eancer hospital for dietary treatment of cancer cases, mainly in inoperable stages. During this period Freund also developed new ideas regarding the pathogenesis of rheumatism, which again he linked up with changes in the intestinal flora. With the annexation of Austria, Mr. Pearson transferred his - foundation to London, where Freund continued his research work with indefatigable zeal.

Freund's enthusiasm and scientific inspiration was matched by a deep devotion to his humanitarian mission. His modesty and profound kindness added to the fascinating charm of his personality, and it was significant that his co-workers wanted to become also his friends, and his friends to become also his co-workers.

R. WILLhEIM

\section{Prof. J. Uzel}

Prof. J. UzEr, professor of agricultural and forest zoology at the Capch Technical College in Prague, died on May 19 Wh the age of seventy-eight. From childbood he was interested in natural science, and he studi for the faculty of science and philosophy at the Unarles University of Prague and at the Unive sity of Berlin.

Utol's chief interest was zoology, especially entomology. His first study was of the group Apterygota. In 1890 he wrote "Šupinušky země České" (Thysanura of Bohemia). For this work he gained an award from the Charles University. Another work on the same group was "Studien über die Entwicklung der Apterygoten Insecten (Berlin, 1898). Meanwhile, as the result of research and careful microscopical observations over a period of years, he produced "Monografie řádu Thysanopter" (a monograph of the order Thysanoptera, 1895). This book, of some five hundred pages, is a fundamental work in this branch of entomology. In it Uzel described many new species of these small, but often serious, agricultural pests. For this book he received an award of the Czech Academy of Sciences.

In 1896 Uzel obtained his doctorate, and then he devoted himself to science and travelling, becoming well known in the scientific world. In 1901 he was invited to Ceylon by Willis, then director of the Royal Botanic Garden in Peradeniya. There he worked as an entomologist for a year. In 1903 the German Government offered him the post of entomologist at the biological station in Amani in Africa. He refused and accepted a position as chief of the research station for the sugar industry in Prague. There he built up a phytopathological department. He took an active part in the protection of sugar beet and published many practical and scientific papers, most of them published in the Zeitschrift für die Zuckerindustrie in Böhmen. During the years 1909-10 he was again studying the fauna in the East Indies and Ceylon.

In 1905 Uzel became a lecturer at the Czech Technical College in Prague, in 1909 he was appointed an extraordinary professor of phytopathology, and in 1920 ordinary professor of agricultural zoology and entomology. Not far from Prague he had a biological station, associated with his institute of zoology. For his scientific work Uzel was in 1905 elected to the fellowship of the Czech Royal Society.

In recent years Uzel took up the study of philosophy. He published many papers, and in 1926 a book in Czech, called "Nature is a Gospel" (German edition: Die Natur ein Evangelium, 1937). In this book he gives a summary of his own philosophical 
views, which had considerable influence on Czech fre日 religious movements.

During his life Uzel collected at home and abroad much entomological material. This is deposited in the Prague Museum, the Agricultural Museum in Prague, the Natural History Museum in Vienna and in the Museum at Peradeniya. His collections in the Zoological Institute at Prague were destroyed by the Germans during the occupation of the country.

Altogether Uzel published some four hundred papers; a chronological survey of them has been published in Czech : "Work and Life of Prof. Dr. J. Uzel" (Prague, 1938).
K. ČẸMÁK
WE regret to announce the following deaths :

Mr. G. H. J. Adlam, O.B.E., editor since 1919 of the Scholl Science Review, on July 30, aged seventy.

My. Asa Binns, formerly chief engineer to the Port of London Authority, and a past president of the Institution of Mechanical Engineers, on July 2, aged seventy-two.

Sir Franeis Carnegie, C.B.E., during 1926-44 chief superintendent of ordnance factories, Royal Arsenal, Woolwich, on August 3, aged seventy-two.

Prof. J. Laird, regius professor of moral philosophy in the University of Aberdeen, on August 5, aged fifty-nine.
816

Mathematical Physics at Cambridge:

Prof. D. R. Hartree, F.R.S.

Prof. D. R. HÁrtree, who has been appointed Plummer professor of mothematical physics in the University of Cambrify, in succession to the late Sir Ralph Fowlepus born in 1897 and educated at Bedales. Durifg the First World War he was a lieutengn in the R.N.V.R., and worked at the Afti-A Mraft Experimental Section at Whale Island af 1 member of a famous team of scientific men under the direction of Prof. A. V. Hill. Going to Cambridge, he took the Natural Sciences Tripos in 1922 and was elected a fellow of St. John's College in 1924. After one year (1928-29) as University demonstrator in physics, Hartree was elected Beyer professor of applied mathematics in the University of Manchester, which post he held until 1937, when he became professor of theoretical physics in the Physical Laboratory at Manchester.

Prof. Hartree's earlier work was mainly connected with the calculation of the energy-levels and wavefunctions of atomic structures. He possesses a great gift and liking for numerical mathematics, and this aptitude he displayed to the full in this field, which he has made peculiarly his own. Later on, when he felt that he had sufficiently exploited 'pencil and paper' methods, he decided that a differential analyser was needed to develop the work further. Taking as a model that of Prof. Bush at the Massachusetts Institute of Technology, a differential analyser was built by Metropolitan-Vickers for Prof. Hartree and housed in the Physical Laboratories, Manchester. This instrument, the first made in Great Britain, has been used for very many other purposes than calculating atomic properties. For example, it has been fully employed during 1939-45 on technical problems for the Services and for industry. During the Second World War, Hartree was employed by the Ministry of Supply on very many problems of importance, particularly in the field of internal ballistics of rockets, of the propagation of radio waves, and of the theory of the magnetron. He was chairman of the Ministry of Supply Panel on servo mechanisms, which has played a very valuable part in co-ordinating work on servo mechanism throughout Great Britain. In 1939 he gave the Kelvin Lecture to the Institution of Electrical Engineers. Recently Hartree's interests in calculating machines have led him to study American work on electronic calculators. $\mathrm{He}$ has just returned from a visit to the United States, where he worked at the University of Pennsylvania with the E.N.I.A.C. (see Nature, April 20, p. 527). Hartree's appointment to the Cavendish Laboratory will bring him into touch with many fields of physies where his mathematical and computational ability will find full scope.

\section{Bacteriology at the University of Sheffield : Prof. C. P. Beattie}

Prof. C. P. Beatrie has been appointed professor of bacteriology in the University of Sheffield in succession to Prof. Wilson Smith, who recently left the University to occupy the chair of bacteriology at University College Hospital Medical School, London. Prof. Beattie was educated at Fettes College and the University of Edinburgh. After clinical and bacteriological experience in the hospitals and University of Edinburgh, he spent a period of study and research in the United States and in France with a Rockefeller fellowship, returning to Edinburgh to be lecturer in bacteriology in 1933. In 1937 he was appointed professor of bacteriology in the Royal Faculty of Medicine of Iraq and director of the Government Bacteriology Laboratory, Baghdad, which he started and organised as the bacteriological centre for the whole of Iraq, charged with the preparation of protective vaccines and sera as well as the conduct of bacteriological examinations. Prof. Beattie's own researches have covered a wide field of diseases, some common in Great Britain, some peculiar to Iraq; among his many other duties was the setting up of a quarantine laboratory for the examination of pilgrims returning from Mecca. Prof. Beattie will take up his duties at Sheffield at the beginning of October.

\section{Anti-Locust Research Centre

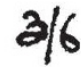

During the War, the Anti-Locust Research Centre concentrated on foregasting and advisory services for anti-locust campaings in Africa and the Middle East ; but now o/gnow for developing research activities has befferde under the Colonial Research and Eeve 60 ment Act, and Dr. D. L. Gunn, formerly of th University of Birmingham, has been appointed Intincipal scientific officer to take charge of this side of the work. It is hoped that the co-operation of university departments, mainly in zoology, can be enlisted, as funds are available to provide some grants to research students willing to undertake laboratory work on selected problems, or to take part in field investigations abroad, particularly in connexion with 